\title{
Distribution of Polymeric Plutonium Injected Intravenously with Different Amounts in Mice
}

\author{
Hisamasa Joshima, ${ }^{*, * 1}$ Masatoshi Kashima ${ }^{* *, * 1}$ \\ and Osamu MATSUOKA ${ }^{* * *, * 1}$
}

(Received October 30, 1979)

\begin{abstract}
Tissue distribution of intravenously injected polymeric plutonium in mice was studied by liquid scintillation counting. The purpose of this study was to know the effect of plutonium administered at different dose levels on its distribution to the tissues. The fraction of deposition and average dose rate to the highly radiosensitive tissues such as the bone marrow and testes were also of our concern.

The polymeric plutonium prepared in this institute was demonstrated to have colloidal properties by showing high deposition in the liver and spleen for a long time. Percent uptakes of plutonium in the main tissues except in the kidneys were not influenced by the three different doses from $5 \mu \mathrm{Ci} / \mathrm{kg}$ to $15 \mu \mathrm{Ci} / \mathrm{kg}$ body weight of ${ }^{239} \mathrm{Pu}$. At 28 days after injection, femoral bone, femoral marrow and testes contained 1.23, 0.18 and 0.063 percent of the injected doses, respectively. At 56 days, the uptakes of the plutonium in the same three tissues were $1.23,0.17$ and 0.057 percent respectively. Average dose rates to the liver, lungs, kidneys, testes and femoral bone were proportional to the amount of plutonium administered. On the other hand, average dose rates to the spleen and bone marrow were characteristic in that they were not proportional to the amount of plutonium administered. Elevated dose rates (rad/day) were obtained in the spleen and the bone marrow, where there were weight losses resulting from the internal exposure to the deposited plutonium. Therefore, radiation dose to the spleen and bone marrow can not be solely obtained in proportion to the administered dose.
\end{abstract}

KEY WORDS: tissue distribution, intravenous injection, polymeric plutonium, mice, liquid scintillation counting, different dose levels, average dose rate, femoral bone, femoral marrow, testes.

\section{INTRODUCTION}

With the accelerated utilization of plutonium in nuclear industry, the possibility of exposure to plutonium has increased in man. It is well known that tissue distribution of plutonium depends on its physical-chemical form, as well as on the route of administration and species. ${ }^{1)}$ Plutonium (IV) ions tend to be readily hydrolyzed to form polymeric product under physiological conditions. A great deal is known about the tissue distribution of intravenously injected polymeric plutonium in

*1 Division of Radiation Hazards, National Institute of Radiological Sciences; 9-1, Anagawa 4-chome, Chiba-shi, Chiba-ken.

* 上島久正, **鹿島正俊, ***松岡 理 放射線医学総合研究所障害基礎研究部; 千葉県千葉市 穴川 4-9-1 (宁 260) animals, ${ }^{1)}$ and administered doses in these studies varied from $0.1 \mu \mathrm{Ci} / \mathrm{kg}$ of body weight to $90 \mu \mathrm{Ci} / \mathrm{kg}$ of body weight of ${ }^{239} \mathrm{Pu}$. On the other hand, little is known about the relation between the administered dose of plutonium and its distribution to the tissues. As partial release of plutonium from the deposited site and re-distribution of released plutonium are anticipated by many investigators, ${ }^{2-5)}$ it is likely that the difference in administered dose of plutonium could affect the release and re-distribution of plutonium itself through radiation damage to the deposited cells. ${ }^{3)}$ The purpose of the present experiment is to know whether the difference in administered dose of polymeric plutonium could affect the distribution of plutonium itself or not. The additional emphasis is put on the observation of the uptakes of plutonium in the bone marrow and testes. For 
these purposes, the intravenous injection of polymeric plutonium was made in mice at three different dose levels, and tissue distribution of the plutonium was observed by liquid scintillation counting.

\section{MATERIALS AND METHODS}

Polymeric plutonium (1.67 $\mu \mathrm{Ci}$ plutonium-239 per mililiter) wat freshly prepared from the stock solution of $\mathrm{Pu}\left(\mathrm{NO}_{3}\right)_{4}$ by careful dropwise addition of $0.01 \%$ sodium citrate and $1 \mathrm{~N} \mathrm{NaOH}$ to $\mathrm{pH} 8$ with molar plutonium: citrate ratio of 2 . Within one hour after preparation thirty-six adult male CF\#1 mice weighing about $33 \mathrm{~g}$, furnished by Technical Service Division of our institute, received a single intravenous injection of polymeric plutonium-239 at the dose levels of $5 \mu \mathrm{Ci} / \mathrm{kg}, 10 \mu \mathrm{Ci} / \mathrm{kg}$ and $15 \mu \mathrm{Ci} / \mathrm{kg}$ of body weight. At 28 days and 56 days after injection of polymeric plutonium, the mice were sacrificed and percent uptakes of the injected dose in the liver, spleen, lungs, kidneys, testes, whole left femur, right femoral bone and right femoral marrow were determined by liquid scintillation counting. ${ }^{6}$ ) The amounts of plutonium deposited in the femoral marrow and femoral bone were determined as follows: Right and left femurs were cleaned off muscle and analyzed for plutonium, separately. First, plutonium content in the whole intact left femur was analyzed. Second, right femur was separated into marrow and bone fraction, and plutonium content in the femoral marrow and femoral bone were separately measured. Separation of the marrow and bone was performed by removing the marrow with syringe needle. A tuberculin syringe needle (Terumo) was pushed into the marrow cavity, and Hank's solution was aspirated backward and forward through cavity until the marrow was removed as much as possible. This procedure was a modification of a technique reported for removal of the bone marrow cells of mice. ${ }^{7)}$ As a small amount of the marrow remains in the deep trabecu-

Table 1. Tissue distribution of plutonium at 28 days after intravenous injection of three different doses of polymeric plutonium.

\begin{tabular}{lrrrr}
\hline & \multicolumn{4}{c}{ Percent of injected dose / tissue (Mean \pm S.D.) } \\
\cline { 2 - 5 } Tissue & $5 \mu \mathrm{Ci} / \mathrm{kg}$ & $10 \mu \mathrm{Ci} / \mathrm{kg}$ & Dose & Average \\
\hline Liver & $46.67 \pm 6.53$ & $51.34 \pm 5.47$ & $53.05 \pm 6.71$ & $50.13 \pm 6.50$ \\
Spleen & $1.03 \pm 0.15$ & $1.07 \pm 0.23$ & $1.26 \pm 0.20$ & $1.12 \pm 0.21$ \\
Lungs & $0.18 \pm 0.06$ & $0.18 \pm 0.06$ & $0.18 \pm 0.09$ & $0.18 \pm 0.07$ \\
Kidneys & $0.73 \pm 0.08$ & $0.63 \pm 0.12$ & $0.56 \pm 0.06$ & $0.64 \pm 0.11$ \\
Testes & $0.07 \pm 0.02$ & $0.06 \pm 0.02$ & $0.05 \pm 0.01$ & $0.06 \pm 0.02$ \\
Left femur (Whole) & $1.40 \pm 0.18$ & $1.35 \pm 0.09$ & $1.48 \pm 0.18$ & $1.41 \pm 0.16$ \\
Right femur (Bone) & $1.21 \pm 0.13$ & $1.13 \pm 0.09$ & $1.33 \pm 0.19$ & $1.23 \pm 0.16$ \\
Right femur (Marrow) & $0.17 \pm 0.06$ & $0.19 \pm 0.02$ & $0.17 \pm 0.05$ & $0.18 \pm 0.04$
\end{tabular}

Table 2. Tissue distribution of plutonium at 56 days after intravenous injection of three different doses of polymeric plutonium.

\begin{tabular}{lrrrr}
\hline & \multicolumn{4}{c}{ Percent of injected dose / tissue (Mean \pm S.D.) } \\
\cline { 2 - 5 } Tissue & $5 \mu \mathrm{Ci} / \mathrm{kg}$ & $10 \mu \mathrm{Ci} / \mathrm{kg}$ & $15 \mu \mathrm{Ci} / \mathrm{kg}$ & Average \\
\hline Liver & $39.25 \pm 3.28$ & $41.22 \pm 7.08$ & $44.09 \pm 4.38$ & $41.52 \pm 5.27$ \\
Spleen & $1.14 \pm 0.23$ & $1.19 \pm 0.11$ & $1.23 \pm 0.40$ & $1.19 \pm 0.16$ \\
Lungs & $0.12 \pm 0.07$ & $0.29 \pm 0.17$ & $0.14 \pm 0.05$ & $0.18 \pm 0.13$ \\
Kidneys & $0.49 \pm 0.02$ & $0.56 \pm 0.09$ & $0.45 \pm 0.06$ & $0.50 \pm 0.07$ \\
Testes & $0.07 \pm 0.02$ & $0.05 \pm 0.01$ & $0.05 \pm 0.02$ & $0.06 \pm 0.02$ \\
Left femur (Whole) & $1.45 \pm 0.20$ & $1.33 \pm 0.05$ & $1.36 \pm 0.09$ & $1.39 \pm 0.14$ \\
Right femur (Bone) & $1.30 \pm 0.20$ & $1.18 \pm 0.13$ & $1.21 \pm 0.11$ & $1.23 \pm 0.15$ \\
Right femur (Marrow) & $0.16 \pm 0.04$ & $0.17 \pm 0.04$ & $0.18 \pm 0.03$ & $0.17 \pm 0.03$ \\
\hline
\end{tabular}


lar recesses of the proximal bone segment and in the proximal epiphysis, marrow was carefully removed under the same conditions. With the exception of this loss, plutonium contents in the marrow and bone were separately measured. The weight of right femur was measured before and after removing the bone marrow, and the weight of bone marrow was obtained.

The average dose rate ( $\mathrm{rad} /$ day) based solely on the uniform distribution of plutonium in the tissues was calculated by using a simple formula. ${ }^{8)}$

\section{RESULTS}

The tissue distribution of plutonium after intravenous injection of polymeric plutonium is shown in Tables 1 and 2. With the increase in administered dose, the percent uptakes in the liver and spleen showed weak increasing tendency, while in the testes the uptakes of plutonium tended to show slight decrease. But statistical analysis indicated no significant difference in the gross distribution of polymeric plutonium among the three different dose levels in these tissues. In the kidneys, at 28 days after injection, the percent uptake of $15 \mu \mathrm{Ci} / \mathrm{kg}$ group $(0.56 \pm 0.06 \%)$ was significantly different from $5 \mu \mathrm{Ci} / \mathrm{kg}$ group $(0.73 \pm 0.08 \%)$. At 56 days after injection, the percent uptake of $15 \mu \mathrm{Ci} / \mathrm{kg}$ group $(0.45 \pm 0.06 \%)$ was significantly different from $10 \mu \mathrm{Ci} / \mathrm{kg}$ group $(0.56 \pm 0.09 \%)$. As the difference in administered dose of polymeric plutonium from $5 \mu \mathrm{Ci} / \mathrm{kg}$ to $15 \mu \mathrm{Ci} / \mathrm{kg}$ did not affect the percent uptake of plutonium in the main tissues except in the kidneys, the results of the three different dose groups have been combined.

Of the plutonium injected intravenously, $50.13 \%$ was deposited in the liver, $1.12 \%$ in the spleen, $0.18 \%$ in the lungs and $0.64 \%$ in the kidneys on the average at 28 days after injection. In the course of the next 4 weeks, from 28 days to 56 days after injection, the plutonium content in the spleen and lungs showed little change. The liver burden of plutonium was lessened gradually and plutonium content in the kidneys was lost very slowly. At 56 days after injection, the fraction of plutonium deposited in the liver was $41.52 \%$, in the spleen $1.19 \%$ and in the lungs $0.18 \%$ on the average. Average uptake of the left whole femur in all the three groups was $1.41 \%$ at 28 days and $1.39 \%$ at 56 days. The right femoral bone whose marrow was removed with repeated flushing by
Table 3. Average dose rate at 28 days after intravenous injection of three different doses of polymeric plutonium.

\begin{tabular}{lcrr}
\hline & \multicolumn{3}{c}{$\begin{array}{c}\text { Average dose rate (rad/day) } \\
\text { (Mean } \pm \text { S.D.) }\end{array}$} \\
\cline { 2 - 4 } Tissue & \multicolumn{3}{c}{ Dose } \\
\hline Liver & $9.61 \pm 0.37$ & $21.89 \pm 2.75$ & $32.25 \pm 2.83$ \\
Spleen & $7.62 \pm 0.53$ & $17.11 \pm 2.67$ & $32.82 \pm 9.23$ \\
Lungs & $0.44 \pm 0.01$ & $0.90 \pm 0.08$ & $1.36 \pm 0.17$ \\
Kidneys & $0.50 \pm 0.05$ & $0.83 \pm 0.04$ & $1.28 \pm 0.15$ \\
Testes & $0.17 \pm 0.03$ & $0.27 \pm 0.05$ & $0.39 \pm 0.07$ \\
Left femur & $6.97 \pm 0.25$ & $12.25 \pm 1.00$ & $18.75 \pm 0.30$ \\
$\quad$ (Whole) & & & \\
Right femur & $7.36 \pm 0.74$ & $14.25 \pm 1.18$ & $22.67 \pm 2.35$ \\
$\quad$ (Bone) & & & \\
Right femur & $3.37 \pm 0.41$ & $6.32 \pm 1.13$ & $8.80 \pm 1.68$ \\
$\quad$ (Marrow) & & & \\
\hline
\end{tabular}

Table 4. Average dose rate at 56 days after intravenous injection of three different doses of polymeric plutonium.

\begin{tabular}{|c|c|c|c|}
\hline \multirow[b]{3}{*}{ Tissue } & \multicolumn{3}{|c|}{$\begin{array}{l}\text { Average dose rate (rad/day) } \\
\text { (Mean } \pm \text { S.D.) }\end{array}$} \\
\hline & \multicolumn{3}{|c|}{ Dose } \\
\hline & $5 \mu \mathrm{Ci} / \mathrm{kg}$ & $10 \mu \mathrm{Ci} / \mathrm{kg}$ & $15 \mu \mathrm{Ci} / \mathrm{kg}$ \\
\hline Liver & $7.80 \pm 0.54$ & $17.63 \pm 1.96$ & $27.65 \pm 2.71$ \\
\hline Spleen & $7.61 \pm 0.93$ & $22.96 \pm 6.47$ & $56.67 \pm 14.00$ \\
\hline Lungs & $0.29 \pm 0.01$ & $1.52 \pm 0.15$ & $1.38 \pm 0.16$ \\
\hline Kidneys & $0.32 \pm 0.04$ & $0.76 \pm 0.09$ & $0.97 \pm 0.12$ \\
\hline Testes & $0.14 \pm 0.02$ & $0.23 \pm 0.04$ & $0.36 \pm 0.06$ \\
\hline $\begin{array}{l}\text { Left femur } \\
\text { (Whole) }\end{array}$ & $6.45 \pm 0.48$ & $12.22 \pm 1.06$ & $18.93 \pm 1.55$ \\
\hline $\begin{array}{l}\text { Right femur } \\
\text { (Bone) }\end{array}$ & $6.61 \pm 0.63$ & $11.24 \pm 1.22$ & $18.10 \pm 1.55$ \\
\hline $\begin{array}{r}\text { Right femur } \\
\text { (Marrow) }\end{array}$ & $6.43 \pm 2.89$ & $21.81 \pm 2.33$ & $36.86 \pm 22.76$ \\
\hline
\end{tabular}

Hank's solution contained $1.23 \%$ of the injected dose at 28 days and 56 days. Plutonium content in the femoral marrow was $0.18 \%$ at 28 days and $0.17 \%$ at 56 days. The mean uptake of plutonium in the testes was $0.063 \%$ at 28 days and $0.057 \%$ at 56 days.

Average dose rate to each organ based solely on the uniform distribution of plutonium in the tissues is shown in Tables 3 and 4 . The average dose rates to the liver, lungs, kidneys, testes and femoral bone were almost proportional to the amount of plutonium administered. For example, at 56 days 
after injection, the average dose rates to the liver were $7.8 \mathrm{rad} /$ day in $5 \mu \mathrm{Ci} / \mathrm{kg}$ group, $17.6 \mathrm{rad} /$ day in $10 \mu \mathrm{Ci} / \mathrm{kg}$ and $27.6 \mathrm{rad} /$ day in $15 \mu \mathrm{Ci} / \mathrm{kg}$ group. On the other hand, average dose rates to the spleen and marrow were characteristic in that they were not proportional to the amount of plutonium administered. For example, the average dose rates to the spleen at 56 days after injection were $7.6 \mathrm{rad} /$ day in $5 \mu \mathrm{Ci} / \mathrm{kg}$ group, $23.0 \mathrm{rad} /$ day in $10 \mu \mathrm{Ci} / \mathrm{kg}$ and $56.7 \mathrm{rad} /$ day in $15 \mu \mathrm{Ci} / \mathrm{kg}$ group.

\section{DISCUSSION}

Phagocytic uptake of the intravenously injected polymeric plutonium by the liver, spleen and bone marrow has been autoradiographically demonstrated. ${ }^{9)}$ On the other hand, partial release of plutonium from the deposition site was anticipated by many investigators. ${ }^{2-5}$ ) For example, leakage of plutonium from the liver to the circulation by radiation damage to the other deposition cells was suggested by LindenBaum et al. ${ }^{2}$ Furthermore, SANDERs has suggested that when intraperitoneally injected ${ }^{239} \mathrm{PuO}_{2}$ was concentrated in phagocytic cells, the damaged phagocytic cells released the engulfed plutonium particles. ${ }^{3)}$ It was also anticipated ${ }^{4)}$ that, either through physical breakdown or through dissolution by endogenous ligands, polymeric plutonium would release some of the ionic plutonium into the blood stream, thus producing a re-distribution of plutonium resulting in a secondary deposition similar to that seen after injection of strictly monomeric plutonium. A sloughing off of the plutonium engulfed cells from the deposition site is also suggested by KASHIMA. ${ }^{5)}$ From these considerations, radionuclide concentrations high enough to cause radiation damage to the deposited cells may result in releasing of engulfed plutonium from the damaged cells and/or in sloughing off of plutonium damaged cells to the circulation. On the other hand, the reduced phagocytosis in the macrophages which had previously engulfed a large mass of plutonium particles ${ }^{10}$ ) and the reduction in the removal of damaged cells in the abdominal cavity ${ }^{11}$ ) were observed as the effect of intraperitoneally injected ${ }^{239} \mathrm{PuO}_{2}$. We have also shown ${ }^{12)}$ the decreased phagocytic function of the spleen and increased phagocytic function of the bone marrow after intravenous injection of polymeric plutonium. In this situation, release of plutonium from the deposited cells and sub- sequent translocation of released plutonium are considered to be influenced by the degree of radiation damage induced by polymeric plutonium itself. Actually it is considered by Lindenbaum that the initial concentration of plutonium in the liver influences hepatic retention of plutonium through radiation-induced hepatic damage. ${ }^{2)}$

When polymeric plutonium was intravenously injected at the dose levels from $5 \mu \mathrm{Ci} / \mathrm{kg}$ to $15 \mu \mathrm{Ci} /$ $\mathrm{kg}$ body weight, no significant difference in the tissue distribution of plutonium was observed. This result indicates that the initial patterns of deposition at the three different doses are about the same. Because of small and slow release and redistribution of plutonium, and/or because of sufficient capability of the cells to receive the released plutonium, the gross distribution of plutonium was not influenced by the different administered doses, as a whole. Furthermore, not all the plutonium released from the injured site has necessarily to leave the original deposition tissue. And it is probable that a fraction of released plutonium is simply transferred within the same organs rather than transported through circulation. In fact, intrahepatic translocation of plutonium from the parenchyma to the sinusoidal endothelium has been observed by TAYLOR. ${ }^{13)}$ Detailed study by using microautoradiographic techniques at higher levels of administered dose would be valuable to know whether the behavior of plutonium would be influenced by the administered amount of plutonium itself. The uptake in the kidneys in $15 \mu \mathrm{Ci} / \mathrm{kg}$ group was significantly small. Whether the decreased uptake in the kidneys with the highest dose has any biological meaning or not remains to be resolved.

As anemia has resulted from the marrow deposition of polymeric plutonium, ${ }^{14)}$ the amount of plutonium in the marrow becomes an important problem in the toxicity of plutonium. Although it has been autoradiographically verified in several laboratories that polymeric plutonium deposits in the bone marrow, only one group has radiochemically analyzed the amount of plutonium in the selected bone marrow. ${ }^{15-19)}$ From these data, the relative ratio of the amount of plutonium deposited in the marrow and whole bone (percent uptake of the injected dose in the marrow/percent uptake of the injected dose in the whole bone) were calculated. In the case of monomeric plutonium, 
from 2.4 to 11.0 percent of the skeletal (bone + marrow) plutonium was located in the marrow fraction. In the case of polymeric plutonium, the amount of plutonium deposited in the marrow fraction was from 14.3 to 60.8 percent of the skeletal plutonium. In the present study about 12.5 percent of the skeletal plutonium was located in the marrow fraction, which seemed to be somewhat smaller than those calculated above. The principally polymeric preparation $(30 \%$ ultrafilterable through visking tube) at Argonne National Laboratory deposited $34 \%$ in the liver, $1.5 \%$ in the spleen and $1.1 \%$ in the femur at 41 days after injection. ${ }^{1)}$ The polymeric plutonium prepared at our institute deposited more in the liver and less in the spleen and femur. On the other hand, monomeric plutonium $(100 \%$ ultrafilterable through visking tube) prepared at Argonne National Laboratory deposited only $4.3 \%$ in the liver, $0.14 \%$ in the spleen and $1.75 \%$ in the femur at 44 days after injection. ${ }^{1)}$ Although the ultrafilterability was not examined in our experiment, the colloidal nature of the plutonium solution in this study was demonstrated by (1) the high deposition of the radioelement in the liver and spleen, (2) the relative permanence of its deposition in the liver and spleen.

Recently, interest has been re-focused on the genetic effect of plutonium in the gonadal tissue. A review on the uptake and retention of plutoniumnitrate, plutonium-citrate and plutonium oxide in the gonadal tissue has been made by RICHMOND and Thomas. ${ }^{20)}$ However, only little attention is paid to the uptake of polymeric plutonium in the gonadal tissue with the exception of mouse ovaries, ${ }^{18)}$ rabbit ovaries ${ }^{18)}$ and dog testes. ${ }^{21)}$ In the present study, the mean uptakes of polymeric plutonium in the testes were $0.063 \pm 0.021$ percent of the injected dose at 28 days and $0.057 \pm 0.016$ percent of the injected dose at 56 days. BAXTeR et al. reported ${ }^{21}$ that 0.00159 percent of the injected dose deposited in dog testes 6 days after intravenous injection of polymeric plutonium. On the other hand, TAYLOR suggested ${ }^{22}$ that the mean uptake of polymeric plutonium in the rat testis was similar to that of monomeric plutonium (0.062 percent level of the injected dose per testis). According to TAYLOR, ${ }^{22)}$ about one third of the alpha tracks lie in the region of the spermatogonia after intravenous injection of plutonium-nitrate. The mean dose of ${ }^{239} \mathrm{Pu}$ given to the rats in his study was $2.4 \mu \mathrm{Ci} / \mathrm{kg}$ body weight. This dose would give an average radiation dose rate to the whole testis of $34 \pm 9 \mathrm{mrad} /$ day and a dose of $54 \pm 14 \mathrm{mrad} /$ day at the spermatogonial stem cells. GREEN et al. reported $^{23)}$ that for mice the radiation dose rate to spermatogonial stem cells was greater by a factor of 2-2.5 than average for the testes calculated directly from the total amount of plutonium deposited in the testis. So, calculation based solely on average dose to testis would underestimate the genetic risk resulting from
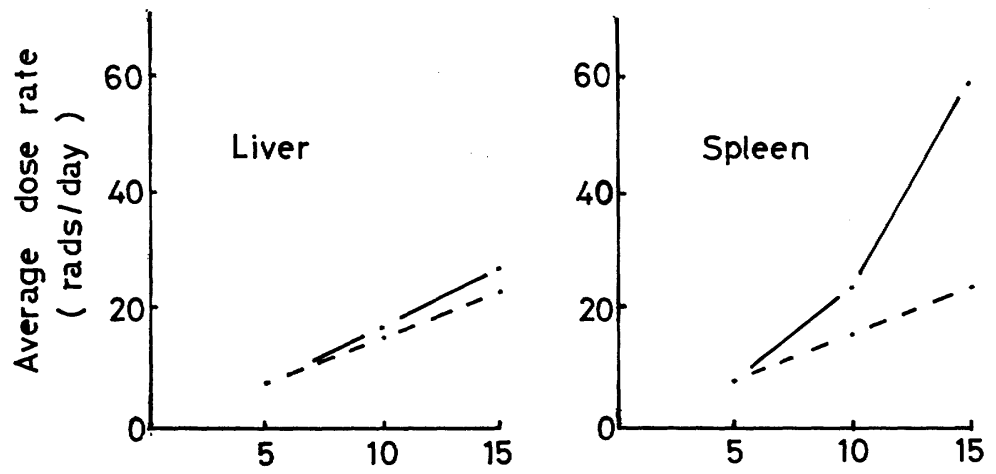

Administered dose ( $\mu \mathrm{Ci} / \mathrm{Kg}$ )

Fig. 1 Average dose rate at 56 days after intravenous injection of three different doses of polymeric plutonium.

- - • , average dose rate estimated by a general formula; - - - •, average dose rate predicted by the results of $5 \mu \mathrm{Ci} / \mathrm{kg}$ group. 
${ }^{239} \mathrm{Pu}$ in the testis. As the non-uniform distribution of polymeric plutonium in the testis is considered to be greater than that of plutonium-nitrate and plutonium-citrate, detailed microscopic study on the distribution of polymeric plutonium in the testis and calculation of dose to the spermatogonial stem cells are desirable in order to evaluate the genetic effect of polymeric plutonium.

The percent uptake of plutonium in main organs except in the kidneys was not influenced by the difference in administered dose after intravenous injection of polymeric plutonium. Average dose rates to the liver, lungs, kidneys, testes and femoral bone were proportional to the amount of plutonium administered but those of the spleen and bone marrow were characteristic in that they were not proportional to the administered dose. The average dose rates to the spleen and bone marrow in $10 \mu \mathrm{Ci} / \mathrm{kg}$ and $15 \mu \mathrm{Ci} / \mathrm{kg}$ group were somewhat more than predicted by the results of $5 \mu \mathrm{Ci} / \mathrm{kg}$ group (Fig. 1). The spleen and bone marrow are very radiosensitive and their weight losses by polymeric plutonium was distinct. For example, at 56 days after injection of $5 \mu \mathrm{Ci} / \mathrm{kg}, 10 \mu \mathrm{Ci} / \mathrm{kg}$ and $15 \mu \mathrm{Ci} / \mathrm{kg}$ of polymeric plutonium, average weight of the spleen was $65 \pm 8,47 \pm 11$ and $28 \pm$ $6 \mathrm{mg}$ respectively. Detailed results concerning the changes in tissue weight will be reported elsewhere. ${ }^{12)}$ Of course the weight of the bone marrow was uncertain. So the average dose rate to the bone marrow was somewhat unreliable. Althogh determination of a true radiation dose from internally deposited polymeric plutonium is a formidable problem, more detailed dose calculation based on microscopic distribution is desirable.

Because of their weight losses, characteristic high dose rates to the spleen and bone marrow were observed. So, it may be pointed out that radiation dose rate to the spleen and bone marrow can not be solely obtained in proportion to the administered dose.

ACKNOWLEDGEMENT: We are grateful to Dr. T. Ishihara for helpful suggestions and a critical reading of the manuscript. We would like to thank Miss. H. Kobayashi for her technical assistance.

\section{REFERENCES}

1) ICRP Pub. 19; The metabolim of compounds of plutonium and other actinides, Pergomon Press, New York (1972).

2) A. Lindenbaum and M.W. Rosenthal; Health Phys., 22, 597 (1972).

3) C.L. SANDERs; Rad. Res., 38, 125 (1969).

4) W. Stevens, D.R. Atherton, D.S. Vuster, B.J. Grube, F.W. Bruenger and A. Lindenbaum; Research in Radiobiology, COO-119-250, P. 128, Univ. of Utah (1975).

5) M. Kashima; Nippon Act. Radiol., 38, 992 (1978).

6) H. Joshima, M. Kashima and O. Matsuoka; Hoken Butsuri, 11, 97 (1976).

7) E.A. McCulloch and J.E. Till; Rad. Res., 13, 115 (1959).

8) A.P. Casarett; "Radiation Biology," p. 34 (1968), Prentice-Hall, Inc., New Jersey.

9) O. Matsuoka, M. Kashima, H. Joshima and Y. NodA; Health Phys., 22, 713 (1972).

10) C.L. SANDers; Health Phys.. 18, 82 (1970).

11) C.L. SAnders and R.R. AdeE; J. Reticuloendoth. Soc., 6, 1 (1969).

12) H. Joshima, M. Kashima and O. Matsuoka; J. Rad. Res., 20, 248 (1979).

13) G.N. TAYlor, W.S.S. Jee, N.L. Dockum, E. HromyK and L. BREWSTER; USAEC Document COO-119-234, p. 70 (1966).

14) H. Joshima, M. Kashima and O. Matsuoka; J. Rad. Res., 17, 192 (1976).

15) A. Lindembaum, C. Lund, M. Smoler and M.W. RosentHAL; "Diagnosis and treatments of deposited radionuclides," p. 56 (1968), Excerpta Medica Foundation, Amsterdam.

16) M.W. Rosenthal, J.H. Marshall and A. LindenBAUM; ibid., p. 73 (1968).

17) M.W. Rosenthal, M. Smoler and A. LindenBAUM; ibid., p. 403 (1968).

18) M.W. Rosenthal, E. Moretti, J.J. Russel and A. Lindenbaum; Health Phys., 22, 743 (1972).

19) M.W. Rosenthal, A. Lindenbaum, J.J. Russel, E. Morftti and D. ChladeK; Health Phys., 23, 231 (1972).

20) C.R. Richmond and R.L. Thomas; Health Phys., 29, 241 (1975).

21) D.W. Baxter, M.W. Rosenthal, J.J. Russell, E. Moretti, D. ChladeK and A. Lindenbaum; Rad. Res., 54, 556 (1973).

22) D.M. TAYLOR; Health Phys., 32, 29 (1975).

23) D. Green, G.R. Howells, E.R. Humphreys and J. VENNART; "The health effects of plutonium and radium," p. 21 (1976), P.J.W. Press, Salt Lake City. 